NO FINISH LINE 



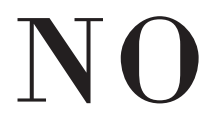

FINISH

LINE

\section{LESSONS ON LIFE}

AND CAREER

\section{Meyer \\ Feldberg}

COLUMBIA UNIVERSITY PRESS

NEW YORK 


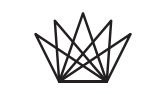

Columbia University Press

Publishers Since 1893

New York Chichester, West Sussex

cup.columbia.edu

Copyright (C) 2020 Columbia University Press

All rights reserved

Library of Congress Cataloging-in-Publication Data

Names: Feldberg, Meyer, author.

Title: No finish line : lessons on life and career / Meyer Feldberg.

Description: New York : Columbia University Press, [2020]

Identifiers: LCCN 2019058736 (print) | LCCN 2019058737 (ebook) |

ISBN 9780231196727 (hardcover) | ISBN 9780231551793 (ebook)

Subjects: LCSH: Feldberg, Meyer. | Business teachers - United States-

Biography. | Management-Study and teaching (Higher) - United States. |

Investment bankers - United States. | Conduct of life.

Classification: LCC HF1131 .F 452020 (print) |

LCC HF1131 (ebook) | DDC 650.1- dc23

LC record available at https://lccn.loc.gov/2019058736

LC ebook record available at https://lccn.loc.gov/2019058737

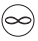

Columbia University Press books are printed on

permanent and durable acid-free paper.

Printed in the United States of America 
To my beloved wife, Barbara, whom I found sitting at a swimming pool in Tel Aviv when she was eighteen, and to our children, Lewis and Ilana, and our six grandchildren,

Sarah, Max, Noa, Adam, Danielle, and Sophia

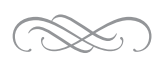

In memory of my parents, Leon and Sarah, and my sister, Abigail (Gaia) 
